\title{
ANALYSIS OF CAPITAL STRUCTURE AND EFFICIENCY OF CAPITAL EMPLOYED IN AGRO-ALLIED FIRMS IN NIGERIA
}

\author{
Nsikan E. BASSEY $1^{*}$, C.J. ARENE ${ }^{2}$, B.C. OKPUKPARA ${ }^{3}$ \\ ${ }^{1}$ Department of Agricultural Economics and Resources Management Akwa Ibom State University, Ikot Akpaden, Mkpat Enin, P.M.B 1167, Uyo, \\ Akwa Ibom State, Nigeria \\ ${ }^{2}$ Department of Agricultural Economics, University of Nigeria, Nsukka, Nigeria \\ ${ }^{3}$ Centre for Entrepreneurship and Development Research, University of Nigeria,Nsukka, Nigeria \\ * Corresponding author e-mail: nebass2005@gmail.com
}

\begin{abstract}
The study examines and compares the capital structure and efficiency of capital employed between listed and unlisted agro-based firms in Nigeria. Data collected from 88 agro-based firms using random sampling technique for the period 2005-2010 were analysed using Z-test, Capital Structure Ratio (CSR) and Return on Capital Employed Ratio (ROCE) analysis as well as descriptive statistics. The result revealed significant differences between the capital structure of listed and listed agro-based firms. Listed agro-based firms recorded the highest debt to equity ratio than their unlisted counterpart. Short term debts also constituted a greater percentage of the total debt ratios of both sample groups. Unlisted agro firms were more efficient than listed firms in terms of return on capital employed. Accordingly, series of recommendations have also been offered.
\end{abstract}

Keywords: Capital Structure; Agro-based firms; Capital Employed JEL: G32

\section{INTRODUCTION}

Since the advent of petroleum oil, the agricultural sector which constituted about $80 \%$ of Gross Domestic Product and employs about $60 \%$ of the active working population in the immediate post-independence era has recorded dismal performance. According to CBN (2011), in 1960, Nigeria had $60 \%$ of global oil palm export, $20-30 \%$ global groundnut export and 15\% global Cocoa export respectively, though these values later dropped by $5 \%$ in 2000. Today, Nigeria is a net importer of agricultural products with a total import value of 630 million. Average import of wheat (165 millions), fish (105 billion), rice (75 billion) and sugar (60 billion), is amounting to a total import bill of 4.2 billion dollars annually. Also, import of food and live animals into the country equal 260.33 billion in 2005, 293.07 billion in 2006 and 299.48 billion in 2008 (CBN,2008).

Undoubtedly, the potential of agro-based firms in reducing this high import value and correcting the dismal performances of the agricultural sector abound. For instance, CBN (1990) posited that small scale agrobased enterprises have higher capacity for generating employment in Nigeria than some large scale enterprises. Because of their role in local and national development and growth of various economies, they are often referred to as „engine of growth and catalyst” for socioeconomic transformation (Onwumere, 2008). In Latin America, Mahamood (2005) in Fadayomi (1988) citing Jones (1971) reported that $60 \%$ of the total output of manufacturing sector is from agro- based firms. Further, Ibrahim (1997) reported that location of agro-based industries in a place comes with it associated employment and other basic amenities. Hence, its establishment in rural areas facilitates socioeconomic development.

Realizing the aforementioned potential of these firms, successive governments of Nigeria have evolved several schemes all directed toward enhancing their viability and performance. Some of these notable schemes in the area of finance include; the establishment of the bank for industry (BOI), creation of the Nigerian Agricultural Cooperative and Rural Development Bank (NACRDB), establishment of Development banks, launching of Small and Medium Scale Investment Equity Scheme (SMIES) in 1999. Others include; enhanced capital allowances up to $50 \%$ to agro-based plants and machineries, payment of minimum tax by firms that make small or no profit do not apply to agro-allied firms, Other policy initiatives in promoting agro-based firms embodied in the Nigerian National Industrial Policy include;

(i) $30 \%$ tax concession for 5 years to agro-allied firms that attain minimum local raw material utilization of $80 \%$ agriculture and $70 \%$ agro-allied

(ii) $100 \%$ Tax holidays for 7 years and additional 5\% depreciation allowance over and above the initial capital depreciation for investment in economically disadvantage area.

(iii) Banks are enjoined to recognize differences in gestation period of agricultural projects and extend grace period of loans to 12-18 months for seasonal staple, cash crops and the construction of storage structures that require small capital outlay, 8-10 
years for short and long fibre pulp wood production and sawn timber production and a minimum of 7 years for rubber production.

(iv) Export and import prohibition of certain agricultural products.

In spite of these huge potential and laudable initiatives of the government, agro-based firms in Nigeria continue to record dismal performances. Presently, there are a total of 650 major agro allied firms in Nigeria, and these industries operate below 30\% capacity (Report on the Third Nigerian Economic Summit, 1996). In Niger Delta Region of Nigeria, Ministry of Niger Delta Region Affairs (2011) reported that traditional industries found in the region are based on manual artisanal techniques, local inputs and skills transferred through family upbringing at the expense of formal training.

Also, preliminary computation of average index of selected agro-based firms in Nigeria 1970 - 2005 by Akpan (2012) revealed decline of commodity indices in the 2001-2005 compared to 1970-1975, e.g. sugar (from 420.3 to 47.7 ), textile (from 110.6 to 94.2 ), foot wear (from 253.6 to 45.0). This further buttress the fact that agro-based sector has not performed satisfactorily. Onwumere (2008) attributed $25 \%$ of the failure of agricultural businesses to finance. In the view of Onwumere and Ige (2000), for agro enterprises in Nigeria to function effectively, extension and other support services as well as enabling environment are indispensable. Other factors include: unplanned capital structure, poor management strategies and deteriorating capacity utilization in the subsector.

Against this backdrop, the study analyses the capital structure and examined the efficiency of capital employed in quoted and unquoted agro- based firms in Nigeria. The specific objectives are to;

(i) describe the characteristics of agro- based firms and their owners;

(ii) analyse the capital structure and examine the relationship between owner's equity and total debt of the firm;

(iii) ascertain whether there are differences in the capital structure among the sampled groups;

(iv) estimate the efficiency of the firms based on return on capital employed;

(v) make useful recommendations for policy direction and management of these firms.

\section{MATERIAL AND METHODS}

\section{The Study Area}

The study was carried out in Nigeria which is part of the African countries that are situated in West Africa. It lies between Latitudes $4^{0}$ and $14^{0}$ North and Longitudes $2^{0} 2^{1}$ and $14^{0} 30^{1}$ East of the Greenwich Meridian. It has a total population of 140,003,542 (NPC, 2006) and land area of approximately 923,708 sq km (FOS, 1989). Location wise, the country has a total boundary of $4047 \mathrm{~km}$ and borders the Gulf of Guinea and lies between Benin in the South West $773 \mathrm{~km}$, Cameroun to the South East 1690 $\mathrm{km}$, Niger in the North 1,497 km and Chad $87 \mathrm{~km}$.

\section{Sampling Methodology}

The study employed multi stage sampling techniques for selecting the firms. The first stage involved the selection of five geopolitical zones out of the existing six in the country. The selected geopolitical zones are South South, South West, South East, North West and North Central. The second stage involved the selection of one State each from the five geopolitical zones. These States are Lagos State (South West), Abia State (South East) and Rivers State (South South), Kano State (North West), Plateau State (North Central). The third stage entailed selecting ten (10) agro-allied firms from each of the States except Lagos where twenty (20) were selected due high concentration of agro industries in the state, making a total of sixty (60) unlisted agro-allied firms through which information were collected. Twenty eight (28) agro firms which have been listed in the Nigerian Stock Exchange (NSE) were sample making a total of sixty eight (68) agro-based firms that were used for the study.

\section{Data Collection}

Data were gathered only from primary and secondary sources. Two groups of agro-allied firms; large quoted firms and unquoted agro firms were sampled for the study. Twenty eight agro firms which have been listed in the Nigerian Stock Exchange (NSE) were sampled. Sixty large unquoted Agro-allied firms (SMEs) were also sampled from the Register of Small and Medium Scale Enterprises Development of Nigeria (SMEDAN) based on our ability to access their financial statements. Data used for the study were gotten from the financial statements of these firms during the period 2005-2010. Other information such as gender of firm owners, educational qualification, and nature of business were obtained with the aid of an interview schedule.

\section{Analytical Technique}

Data were analysed using both descriptive and inferential statistics. Apart from mean, simple percentages and standard deviation, other analytical tool used were Capital Structure Ratio, Z-test and Return on Capital Employed Ratio Analysis.

Capital Structure Ratio was used to ascertain the percentage contribution of firm owners and creditors to the business over a time period. The capital structure ratio (CSR) (Eq. 1) was calculated according to Welsch and Short, (1987), Matulich and Heitger, (1980), and Arene and Ndomadu (1997).

$$
\mathrm{CSR}=\frac{T L}{T O E}=\frac{\sum(L \mathrm{t} L, D, C, B, A x C I T, V)}{\sum(E, P, R)}
$$

Where: CSR = Capital Structure Ratio; $\mathrm{TL}=$ Total liability or Debts otherwise called total creditors' equity; $\mathrm{L}_{\mathrm{t}} \mathrm{L}=$ Long- term Loan; $\mathrm{D}=$ Debentures; $\mathrm{C}=$ Creditors; $\mathrm{B}=$ Bills Payable; $\mathrm{A}_{\mathrm{x}}=$ Accrued Expenses; CIT = Company Income Tax (Provision for Tax); $\mathrm{V}=$ Value Added Tax; TOE = Total Owners' (Shareholders') Equity; $\mathrm{E}=$ Equity (Ordinary) Share Capital; $\mathrm{P}=$ Preference Share Capital; R = Retained Earnings (or Reserves and Surpluses). 
Z-test (Eq. 2) was used to find out whether there was significant difference in debt and equity use between agro listed and agro unlisted firms. This test was also used to compare the mean debt ratios between listed and unlisted agro firms.

$Z_{\text {cal }}=\frac{\bar{x}_{1}-\bar{x}_{2}}{\sqrt{\frac{s_{1}^{2}}{n_{1}}+\frac{s_{2}^{2}}{n_{2}}}}$

Where: $\mathrm{Z}_{\mathrm{cal}}$ is the calculated value of $\mathrm{Z}$ distribution; $\bar{x}_{1}$ is the mean debt ratio for listed firms; $\bar{x}_{2}$ is the mean debt ratio for unlisted agro-firms; $S_{1}^{2}$ is the variance for the listed agro allied firms; $S_{2}^{2}$ is the variance for the unlisted agro allied firms.

Decision rule: Reject the null hypothesis if the calculated value for $\mathrm{Z}$ is greater than its tabulated value.

Return on Capital Employed Ratio Analysis (Eq. 3) was employed according to Arene (2008), to ascertain the efficiency of capital invested in the business. The ratio shows how well the firms have utilized the capital invested. The higher the ratio, the more efficient and profitable the firms are.

Return on Capital-Employed Ratio =

Net Pr ofit after Tax

\section{RESULTS AND DISCUSSION}

\section{Descriptive Statistics of Agro-Allied Firms}

Analysis of the descriptive statistics for listed and unlisted agro allied firms revealed that listed firms have higher long term (0.6029) and short term (0.7421) debt ratios than unlisted firms with long and short term debt ratios of 0.1651 and 0.5044 respectively. Unlisted agroallied firms were found to have the highest asset value (22.63\%) compared to listed firms with mean asset value (15.22\%). In terms of asset structure, unlisted firms were found to have the highest fixed asset with mean value of 64.4 percent than listed firm with 44.81 percent value. Profitability wise, unlisted firms were more profitable (28.65\%) than listed firms (10.36\%), probably due to their frequent investment in risky projects.

Unlisted agro firms were also found to be the fastest growing firms with mean growth rate of 25.3 percent compared to a growth rate of 15.46 percent recorded by listed firms. The plausible explanation for this is that, since unlisted firms are high risk investors, they dabble into risky and profitable businesses through which means they are able to expand their scope of businesses. In terms of dividend payout, listed firms recorded the highest dividend payout of 0.5204 compared to 0.0971 recorded by unlisted firms. Further, unlisted firms were found to be the highest risk takers with mean value of 1.5048 against 0.3446 recorded by listed agro firms. This justifies the high growth rate value recorded by unlisted agro firms. Also, the average tax rates for listed and unlisted agro firms were 33.23 percent and 45.04 percent, implying that unlisted firms paid more taxes than listed firms. The possible explanation for this is that unlisted agro firms are worst hit by illegal taxes and fraudulent activities of touts.
The average ages of listed and unlisted firms were 39.4 and 8.5 years, with listed firms being older than unlisted firms. About 96.7 and 76.7 percent of chief executive officers of listed and unlisted firms had degree or professional qualification. Also, 93 and 80 percent of the sample agro-based firms were male owned. In terms of export status, about 98.7 and 73.3 percent of listed and unlisted firms engaged in export.

\section{Analysis of Capital Structure of Agro-Allied Firms}

Of the total capital, $12,051,335,491$ and $5,046,518,471$ employed by listed and unlisted agro firms, debt constituted 5,053,142,820 and $1,772,254,757$, while equity comprised 6,998,192,671 and 3,274,263,721 (Table 1). This represented about 41.93 and 35.12 percent debts for listed and unlisted agro firms. It also represent about 58.07 and 64.88 percent equities for listed and unlisted agro firms respectively. Consequently, unlisted agro firms recorded a higher percentage $(64.88 \%)$ of equity as a percentage of total capital employed compared to listed firms (58.07\%). This is an indication that unlisted agro firms used more equity funds than listed agro firms.

Findings further revealed that listed firms recorded the highest debt to equity ratio of 0.7220639 (72.2\%) compared with 0.54126879 (54.1\%) recorded by unlisted firms. This higher leverage ratio recorded by listed firms than unlisted firms indicated excessive indebtedness, signalling that listed firms might be unable to satisfy their obligations on its bond, hence, more risky than their unlisted counterparts. According to Arene and Ndomadu (1997), such firms are shouldering more risk and enjoying less margin of safety in the business than their owners. In their view, investors may be unwilling to invest in such firms (listed firms in this case) for fear of loss of financial resources should the business go bankrupt.

The result of the Z-test revealed a significant difference in debt and equity use by listed and unlisted agro firms at the $5 \%$ and $10 \%$ level of probabilities respectively. It also indicated a significant difference in total capital employed between listed and unlisted firms at the one percent level of significance. Hence, the null hypothesis that owner's equities and liabilities are not different was rejected. The calculated Z-values are greater than their corresponding tabulated $\mathrm{Z}$ values at the 5 and 10 percent significance levels.

\section{Differences in Capital Structure of Listed and Unlisted Agro-allied Firms in Nigeria}

Based on the Z-test results, we found a statistically significant difference in the mean debt ratios of listed and unlisted agro firms (Table 2). This implied that listed agro firms attracted more debts in their capital structure than their unlisted counterparts. Since the calculated Z (3.1317) was greater than the tabulated Z (0.025) with 86 degree of freedom (1.980), the null hypothesis that there is no significant difference in the mean total debt ratios between listed and unlisted agro firms was rejected. 
Table 1: Capital structure ratio analysis for the sampled agro-based firms.

\begin{tabular}{lrrrrrr}
\hline Firm & $\begin{array}{r}\text { Debt } \\
\text { (Naira) }\end{array}$ & $\begin{array}{r}\text { Equity } \\
\text { (Naira) }\end{array}$ & $\begin{array}{r}\text { TCE } \\
\text { (Naira) }\end{array}$ & $\begin{array}{r}\text { Debt as } \\
\text { \% of TCE }\end{array}$ & $\begin{array}{r}\text { Equity as } \\
\text { \% of TCE }\end{array}$ & CSR \\
\hline Listed & $5,053,142,820$ & $6,998,192,671$ & $12,051,335,491$ & 41.93 & 58.07 & 0.7226 \\
Unlisted & $1,772,254,757$ & $3.274,263,721$ & $5,046,518,471$ & 35.12 & 64.88 & 0.5412 \\
Z-stat & $2.4215^{* *}$ & $1.9862^{*}$ & $2.9734^{* * *}$ & & & \\
\hline
\end{tabular}

Note: TCE = total capital employed, CSR refers to the capital structure ratio.

$* * *, * *$ and $*$ represent significant at $1 \%, 5 \%$ and $10 \%$

Source: Computed From Field Survey Data, 2012

This difference can be attributed to differences in firm size. Large sized firms are highly tangible and as a result, access more debt than smaller sized firms. This finding is surprising given that large listed firms have constant access to equity finance and are expected to make use of more equity funds at the expense of debt capital. This finding corroborates Abor (2008), who reported significant differences in mean debt ratios between large quoted and unquoted firms as well as SMEs in Ghana.

Table 2: Mean debt ratio tests between listed and unlisted agro-allied firms

\begin{tabular}{lrrr}
\hline Firm groups & $\begin{array}{r}\text { Long } \\
\text { term debt } \\
\text { ratio }\end{array}$ & $\begin{array}{r}\text { Short } \\
\text { term debt } \\
\text { ratio }\end{array}$ & $\begin{array}{r}\text { Total debt } \\
\text { ratio }\end{array}$ \\
\hline $\begin{array}{l}\text { Listed firms } \\
\text { Unlisted }\end{array}$ & 0.6029 & 0.7421 & 1.345 \\
firms & 0.1651 & 0.5044 & 0.6695 \\
Z- statistics & $2.4646 * *$ & 1.5779 & $3.1317 * * *$ \\
\hline$* * * *$ Significant at $1 \%$ and5\%. & & \\
Source: Computed by author from Field survey data, 2012.
\end{tabular}

The result further showed that long term debt represents about 60.3 and $16.5 \%$ of the total assets of listed and unlisted firms while short term debt represented about 74.2 and $50.5 \%$ of the total assets of listed and unlisted agro firms, respectively. This shows the importance of short term debt over long term debt financing within the firms under investigation. Abor, (2008), Hall et al. (2004) and Sogorb-Mira (2005) all reported similar results.

\section{The Efficiency of Capital Employed in Agro-allied Firms in Nigeria.}

Unlisted firms had the highest return on capital employed ratio (10.31\%) than their listed counterparts (6.114\%) (Table 3). This indicates that unlisted firms, in spite of their poor access to debt finance, were more efficient than listed firms in terms of efficiency of capital employed. This further justifies the higher mean profitability percentage of $28.65 \%$ recorded by unlisted firms against the $10.36 \%$ recorded by listed firms.

\section{CONCLUSIONS}

The study examined and compared the Capital Structure and efficiency of listed and unlisted agro-based firms in Nigeria using data collected from 88 agro firms. The study has shown that both listed and unlisted agro based firms exhibit different financing behaviour and that owners of these firms patronizes more short term debt providers than long term. Also, in spite of poor access to debt finance, unlisted agro-based firms were more efficient than their listed counterpart in terms of return on capital employed. It is the view of the researcher that the result of this study will add to the pool of knowledge that already existed on capital structure and efficiency of capital employed in Nigeria. The sooner the better if the policy implications of this study are adhered to.

\section{Recommendations}

- $\quad$ Given that unlisted agro-allied firms were found to be more profitable than listed firms, presumably due to their high use of equity, appropriate policy measures that would encourage access to publicly quoted equity should be vigorously pursued. Such policy measure should be directed towards reducing listing requirement, subsidizing cost of floating shares and private placement. - $\quad$ Agro-allied firms should be encouraged to keep adequate records. This would enable them ascertain their present and future capital requirement. It would also enable them measure their firm's profitability level.

- $\quad$ Agro listed and unlisted firms were found to use more short term debts than long term debts. Hence, if debts must be use, effort should be directed towards encouraging them to use more long term debts. Enlightenment campaigns in the areas of available cheap long term credit sources at concessionary interest rate and less stringent conditions should be carried out by financial stakeholders. This would assist them acquire more tangible assets with which to improve upon their performances and enjoy economy of scale.

Table 3: Estimation of the efficiency of capital employed in agro- allied firms

\begin{tabular}{lrrrrr}
\hline Firm type & NPAT & Debt (Naira) & Equity (Naira) & TCE (Naira) & $\begin{array}{r}\text { ROCE } \\
\text { ratio } \\
\text { (Naira) }\end{array}$ \\
\hline Listed & $736,812,236$ & $5,053,142,820$ & $6,998,192,671$ & $12,051,335,451$ & $6.11 \%$ \\
Unlisted & $520,313,085$ & $1,772,254,757$ & $3.274,263,721$ & $5,046,518,471$ & $10.31 \%$ \\
Total & $1,257,125,321$ & $6,825,397,577$ & $10,272,456,392$ & $17,097,853,922$ & \\
\hline
\end{tabular}

TCE = total capital employed, ROCE = return on capital employed ratio. NPAT $=$ Net profit after tax.

Source: Computed from Field survey data, 2012. 


\section{REFERENCES}

ABOR, J. (2008). Determinants of Capital Structure of Ghanaian Firms. AERC Research. Paper 176 African Economic Research Consortium, Nairobi

AKPAN, S. B (2012). Analysis of Capacity Utilization Rate in Sugar Industry in Nigeria (1970-2010). Unpublished Doctorate Dissertation Submitted to the Department of Agricultural Economics, Michael Okpara University of Agriculture, Umudike, Nigeria.

ARENE, C. J. - NDOMADU, S.O. (1997). Impact of Value- Added Tax on the capital structure and Profitability of Premier Breweries Plc, Nigeria, Vikalpa, Vol.22, No.3, pp. 71-77.

ARENE, C.J. (2008). Economic Analysis of Agricultural and Rural development Projects (Planning, Appraisal, Implementation and Evaluation). Nsukka, Prize Publishers.

CENTRAL BANK OF NIGERIA (2011). Integrating Nigeria's Agricultural and Financial Value chains: The Role of Nigerian Incentive Based Risk Sharing for Agricultural Lending (NIRSAL), November 16, 2011.

CENTRAL BANK OF NIGERIA (2008). The CBN partnership with Alliance for a Green Revolution in Africa (AGRA): Conceptual Issues, Operation and Prospects for food Security in Nigeria. Economic and Financial Review, Vol.48/4, December, 2008

CENTRAL BANK OF NIGERIA (1990). Annual Report and Statement of Account for the year ended 1990, Lagos, Nigeria.

FADAYOMI T.O. (1988) Rural Development and Migration in Nigeria.The impact of the Eastern Zone of Bauchi State Agricultural Development. Project interprinters
FEDERAL OFFICE OF STATISTICS (1989).Yearly Economic Review, December.

HALL, G.C. - HUTCHINSON, P.J. - MICHAELAS, N.(2004). Determinants of the Capital Structures of European SMEs. Journal of Business Finance and Accounting, 31(5/6): 711-28. http://dx.doi.org/10.1111/j.0306-686X.2004.00554.x MATULICH, S - HEITGER, L. E (1980). Financial Accounting- Financial Analysis; Ratio Analysis. New York: McGraw-Hill, pp 740-755

SOGORB-MIRA, F. (2005). How SME uniqueness affects capital structure: Evidence from a 1994- 1998 Spanish data panel. Small Business Economics, 25: 44757. http://dx.doi.org/10.1007/s11187-004-6486-8

IBRAHIM A. A. (1997) The Socio-economic implication of Zaki Flour Mills on inhabitant of Azare. Geography Department F.U.T Yola.

MINISTRY OF NIGER DELTA AFFAIRS (2011). Federal Republic of Nigeria. Available online at http://www.MNDA.gov/ng/resources/downloadresources. last Accessed August 24th , 2013.

NATIONAL POPULATION COMMISSION (2006). Census Report, Abuja, Nigeria

ONWUMERE, J. - IGE, C.S (2000). Economic Development - Meaning. Measurement and Relevance. Longman Publishers.

ONWUMERE, J. (2008). Policy Issues in enhancing the output of Agricultural business Small and Medium Scale Piggery Enterprises (AGRI-SMEs) in Abia State. Journal of Agricultural Extension, Vol.12. No.2.

Report on the Third Nigerian Economic Summit (1996). Industrial Strategy, Pp 96-99.

WELSCH, G. A - SHORT, D. G (1987). Fundamentals of Financial Accounting ( $5^{\text {th }}$ edition), Homewood 